\title{
Defined Experimental Unit Allocation Method Code
}

National Cancer Institute

\section{Source}

National Cancer Institute. Defined Experimental Unit Allocation Method Code. NCI

Thesaurus. Code C93769.

A coded value specifying the technique that is used for allocating experimental units. 